\title{
COMPUTER SIMULATION IN MECHANICS TEACHING AND LEARNING: A CASE STUDY ON STUDENTS' UNDERSTANDING OF FORCE AND MOTION
}

\section{SIMULASI KOMPUTER DALAM PEMBELAJARAN MEKANIKA: STUDI KASUS PADA PEMAHAMAN SISWA TENTANG GAYA DAN GERAK}

\author{
Dyah Permata Sari ${ }^{1, a}$ dan Madlazim ${ }^{2, b}$ \\ ${ }^{1}$ Science Education, Postgraduate Program, Universitas Negeri Surabaya \\ ${ }^{2}$ Physics Department, Faculty of Mathematics and Natural Sciences, Universitas Negeri Surabaya \\ Jl. Ketintang, Surabaya 60231, Indonesia \\ e-mail: adyahdyahpermata@gmail.com \\ bmadlazim@unesa.ac.id
}

\begin{abstract}
The objective of this research was to develop a force and motion simulation based on the open-source Easy Java Simulation. The process of computer simulation development was done following the ADDIE model. Based on the Analysis and Design phases, the Development phase used the open-source Easy Java Simulation (EJS) to develop a computer simulation with physics content that was relevant to the subtopic. Computing and communication technology continue to make an increasing impact on all aspects of education. EJS is a powerful didactic resource that gives us the ability to focus our students' attention on the principles of physics. Using EJS, a computer simulation was created through which the motion of a particle under the action of a specific force can be studied. The implementation phase is implemented the computer simulation in the teaching and learning process. To describe the improvements in the students 'understanding of the force and motion concepts, we used a t-test to evaluate each of the four phases. These results indicated that the use of the computer simulation could improve students' force and motion conceptual competence regarding Newton's second law of motion.
\end{abstract}

Keywords: computer simulation, open source, student's understanding

\begin{abstract}
Abstrak
Tujuan dari penelitian ini untuk mengembangkan simulasi tentang gaya dan gerak berbasis aplikasi open-source Easy Java Simulation. Proses pengembangan simulasi komputer telah dilaksanakan dengan menggunakan model ADDIE. Berdasarkan pada fase Analysis dan Design, fase Development menggunakan software open-source Easy Java Simulation (EJS) untuk mengembangkan simulasi komputer dengan materi fisika yang relevan dengan subtopik Gaya dan Gerak. Perkembangan teknologi komputasi dan komunikasi memberikan dampak terhadap semua aspek dalam pendidikan. EJS merupakan sumber daya edukasi yang memberikan kita kemampuan untuk memfokuskan perhatian siswa kita pada prinsip-prinsip fisika. Simulasi komputer telah dibuat dengan menggunakan EJS untuk mempelajari gerak dari sebuah partikel dalam pengaruh gaya. Fase Implementation dengan menerapkan simulasi komputer di kegiatan belajar mengajar. Untuk mendeskripsikan peningkatan pemahaman siswa tentang konsep gaya dan gerak, digunakan uji-t
\end{abstract}

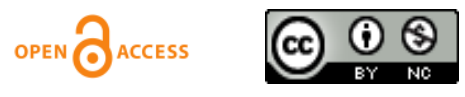


untuk mengevaluasi keempat fase. Hasil menunjukkan bahwa penggunaan simulasi komputer dapat meningkatkan pemahaman konseptual siswa tenang gaya dan gerak berdasarkan hukum kedua Newton.

Kata kunci: simulasi komputer, open source, pemahaman siswa

Copyright@2015 Jurusan Fisika FMIPA Universitas Negeri Surabaya

\section{INTRODUCTION}

Computers can improve both students' understanding of conceptual physics and the teaching and learning process by offering new possibilities, such as bringing exciting and real-world-based curricula into the classroom, providing new tools to enhance teaching, giving students and teachers more opportunities for interaction, building local and global communities and expanding opportunities for teacher or lecturer learning [1]. Computer simulations can be open learning environments that allow students to follow a process of hypothesis-making and idea-testing, to isolate and manipulate parameters, to employ a variety of representations and to investigate physics phenomena that would not be possible to study in a classroom or laboratory [2]. In sum, computer simulations help us reach a deeper level of conceptual learning that helps uncover student difficulties of a more subtle nature. Thus, there is a list of recommended behaviors that are considered as best practices and can facilitate learning by engaging students in explorations that reflect real science: students do science (not just learn about science), students engage in inquiry, students communicate, students collect, manipulate and use data, students work collaboratively in groups. Teachers use authentic assessment, teachers facilitate learning, teachers emphasize relations to real life, teachers integrate science, technology and mathematics, teachers offer depth versus breadth, teachers build on prior understandings and teachers use a variety of materials for learning [3].
Students are familiar with Newton's Laws because they have studied them since Middle or High School. Most of them, having memorized Newton's Laws, can recite each word of Newton's Laws of motion. Indeed, they have no difficulty in formulating and applying the simple motion law equation: $F=$ ma. However, they do not have a clear understanding and, moreover, do not believe Newton's Laws. Just because they know what the laws say does not mean that they have a clear understanding of what the laws mean. This is because students have common sense concepts about motion, and in most cases, those concepts are Aristotelian. It took approximately 2000 years to move from the Aristotelian concept of motion to the Galilean and to believe that force is changed because of motion, for example, that a net force is required to keep an object in motion at a constant velocity. We should not be surprised to find that the concept is a problem for ordinary students today. Accordingly, instructors should treat common sense beliefs with genuine respect [4]. These common sense beliefs are difficult to change and come from daily experience. For example, although the words position, velocity and acceleration are different, they have the same meaning for most students, and it is precisely this type of misconception makes it difficult to understand the laws of motion [5]. These misconceptions are reinforced by way in which Newton's laws are treated in most high school and undergraduate textbooks. They leave the students with formulas, e.g., $F=m a$, but virtually no understanding of the content and meaning of the second law [6]. 
Thus, why are computer simulations not more frequently used in our classrooms? The answers are varied and include resistance to change, ignorance of the results of Physics Education Research, resistance to accept solutions coming from other people, reluctance to use a technology that they, the teachers, do not fully understand or control and the fact that the existing simulations do not quite fill the needs of the teacher or of her students. To solve this problem, it is required to use open-source software or develop computer simulations that meet the required technical level, to increase the teacher's or lecturer's abilities, to make the software accessible in terms of size and effort, to allow a different focus on the curriculum and to allow an active interchange of experiences [7].

With this in mind, we introduce Easy Java Simulation (EJS) [8, 9, and 10]. EJS is an easy-to-use tool that creates scientific simulations in Java and designed by science teachers for science teachers and students. EJS allows users to develop simulations by using their understanding of the scientific model and takes care of all computer-specific tasks, resulting in an independent, high-quality Java application or applet that is ready to be published on a Web server. EJS can serve as an effective teaching and learning tool if it is used in an appropriate pedagogical setting. This article describes a computer simulation developed using the open-source EJS platform and examines the post-test scores of both the experiment and control groups to ascertain whether the computer simulation can improve students' understanding of the concept of force and motion.

\section{RESEARCH METHOD}

The computer simulation development process used in this study was based on the
ADDIE (Analysis, Design, Develop, Implementation, and Evaluation) model. The ADDIE model was developed by Royce in 1970 [11]. It has five phases that comprise the standard basic model for almost all Instructional Design. It is referenced in several documents proposing standard design processes [12, 13]. The five phases are shown in Figure 1.

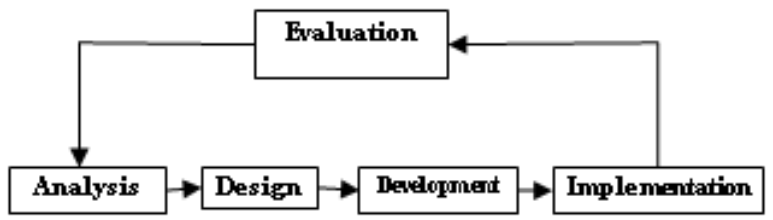

Figure 1. Five phases of the ADDIE model

\section{Analysis}

This step is the description process of the concept to be taught (Newton's second law that consists of force: magnitude and direction, and motion: position, velocity and acceleration) and forms the basis of all other steps. In this step, the designer determines the needs and the difference in the behaviors, knowledge and skills that the learners presently have and the behaviors that they must have or are expected to have. In other words, needs analysis is conducted. The system is analyzed, and the problem and the roots of the problem are described. The constraints are determined, and the possible solutions for the problem are identified.

\section{Design}

This is the determination process of how Newton's second law is going to be learned. In this step, a set of specifications for an effective, efficient and relevant learner environment is designed. The development strategy is determined in accordance with the data obtained during the analysis phase and how the objectives will be reached is clarified. In other words, this is where the instruction method, learning activities and evaluation process become clear. During the 
analysis process, the tasks are separated into learning steps; thus, the design can be implemented in a more accurate and easy way.

\section{Development}

All of the components of the computer simulation are prepared during this phase. This includes producing the computer simulations and gathering all of the tools and support materials that will be used during instruction. The computer simulation is created during this phase; an evaluation, which is mostly for correction, is made; and modifications are carried out as necessary. A detailed plan that was prepared during the phases of analysis and design is implemented, all of the components of the learning environment are developed, and the environment is prepared for the test.

Computer simulation of the ramp plane system development in this study used the open-source, EJS platform. The user interface of EJS is very simple. The basic structure of the simulation is divided into a Model and View, to which a first introductory part is added. Each part also has a dedicated editor that helps the user build the simulation. The interface for the Introduction provides a WYSIWYG editor of HTML pages for the simulation. Each of the introduction pages will turn into a real HTML page when the simulation is generated. The set will include an HTML page for the simulation as a Java applet.
The interface for the Model-Variables (mandatory) provides a left-to-right procedure to specify the model. The first sub-panel allows the definition of the variables that describe the mathematics model of the ramp plane system. The user only needs to type a line for each of the variables. The interface for Model-Initialization (optional) provides additional pages of Java code that can be written to initialize the model. The user needs to write valid Java code but only to express algorithms. The editor provides specialized help. The interface for the Model-Evolution (mandatory) allows the evolution to be specified with pages of plain Java code (as with the initialization) or with a dedicated ODE editor. The editor automatically generates the code for different solving algorithms. The editor supports arrays and events. The interface for the Model-Events allows the definition of a condition or variables of an ODE of Newton's second law (Figure 2). The system detects and finds the precise moment for the event and applies a corrective action. This is all automatically generated. The interface for the Model-Fixed Relations (optional) allows for constraints to express additional relationships between variables. These relationships must also be expressed through user input. They are implemented using pages of Java code. The interface for the Model-Custom (optional) allows custom pages of Java code to be created to host extra methods (subroutines and functions) for our code. This code must be explicitly used by the user in the other parts as well. 


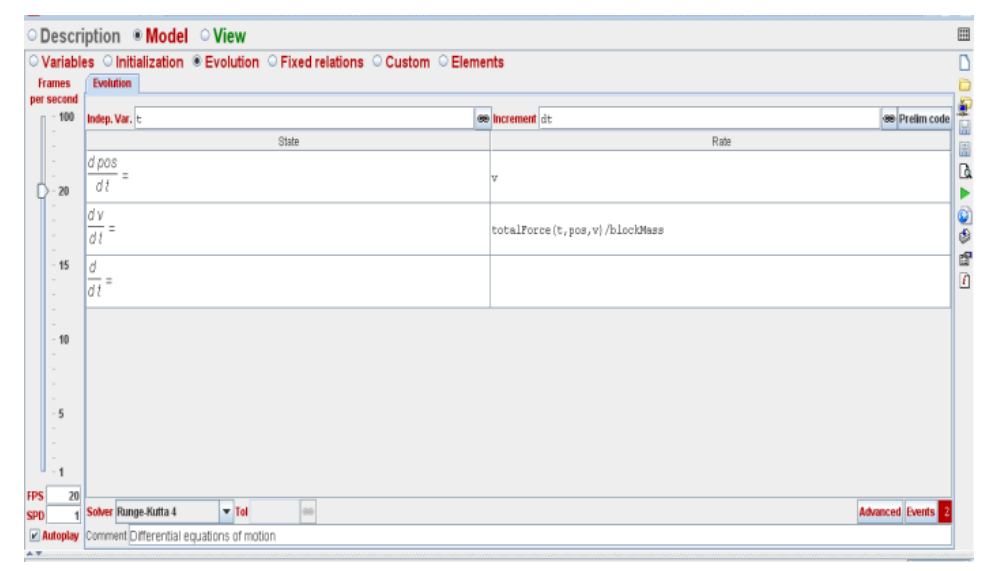

Figure 2. A screen shot of Model-Evolution for the ramp plane system simulation

The interface for the View allows the creation of the view and consists of building an appropriate tree-like structure of the view elements of the physics model of the ramp plane system. Each view element is as a building block specialized in a given visualization or input task. Elements are taken from the list on the right using a simple click-and-create procedure. View elements can be customized by editing their so-called properties. The property can be given a particular constant value, but it can also be linked to a model variable. This establishes a two-way connection that turns the simulation into a real, dynamic, and interactive visualization of the ramp plane system. Running the simulation, i.e., clicking the "Run" button completes the trick. The simulation can be run as an independent application [10, 14, 15, and 16]. A flowchart for designing the computer simulation is shown in Figure 3.

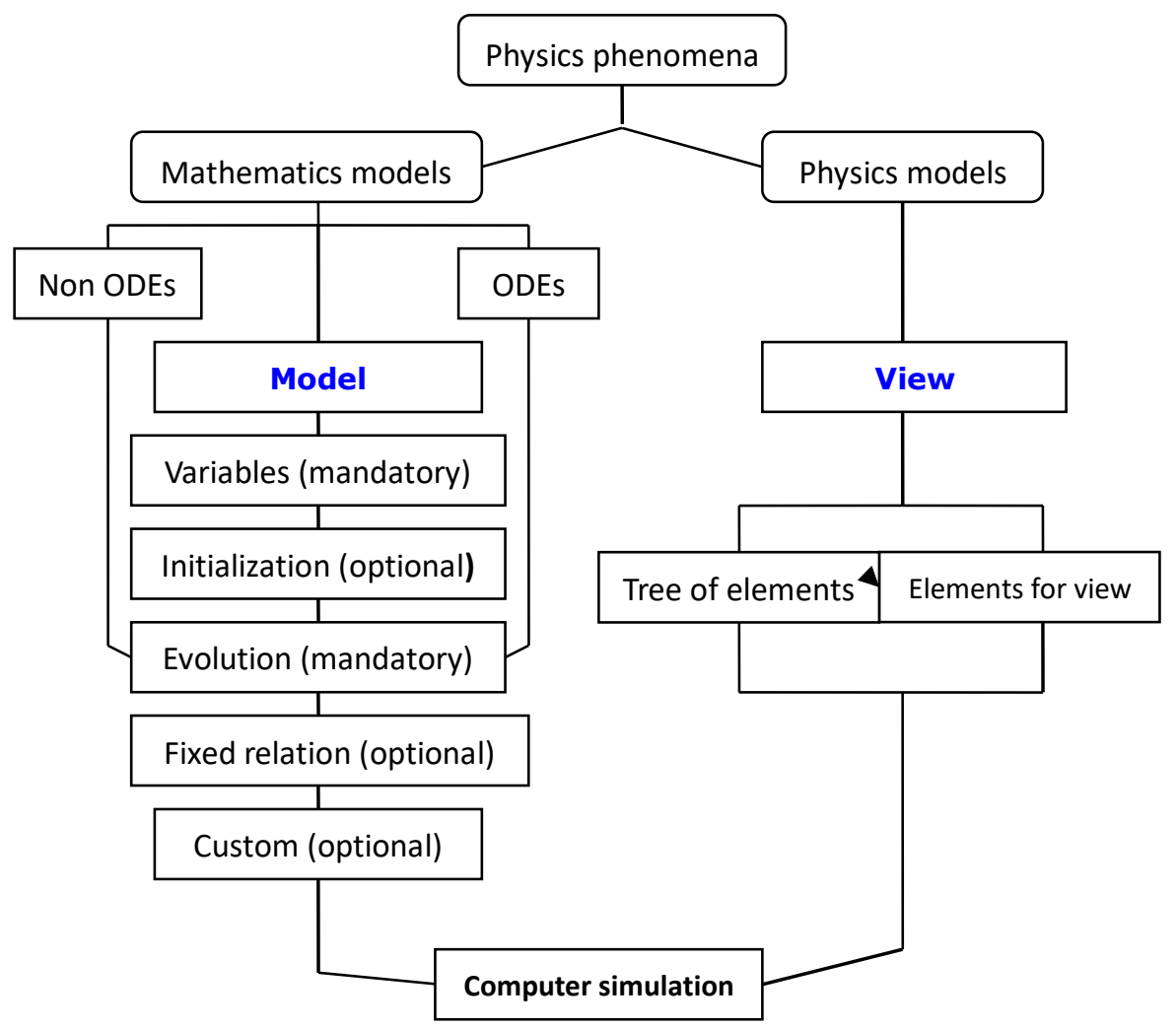

Figure 3. Flowchart to design computer simulation using open- source EJS 
This ramp plane system simulation was designed using open-source EJS. The system consists of one ramp plane and one block. The coefficient of friction between the surface of the ramp plane and the block is $\mu$. A screen shot from this modified simulation is given in figure 4 and explores the role of initial position of the block, ramp plane, and friction coefficient, mass block (m) to the forces system, velocity and acceleration of the motion of the block sliding on the ramp plane. The modified simulation shows corresponding graphs of the total force, acceleration, and velocity of the block versus time. The students can observe the forces of system and velocity and the acceleration of the block sliding on the ramp plane simultaneously with the graphical representation of motion $[17,18$, 19, and 20].

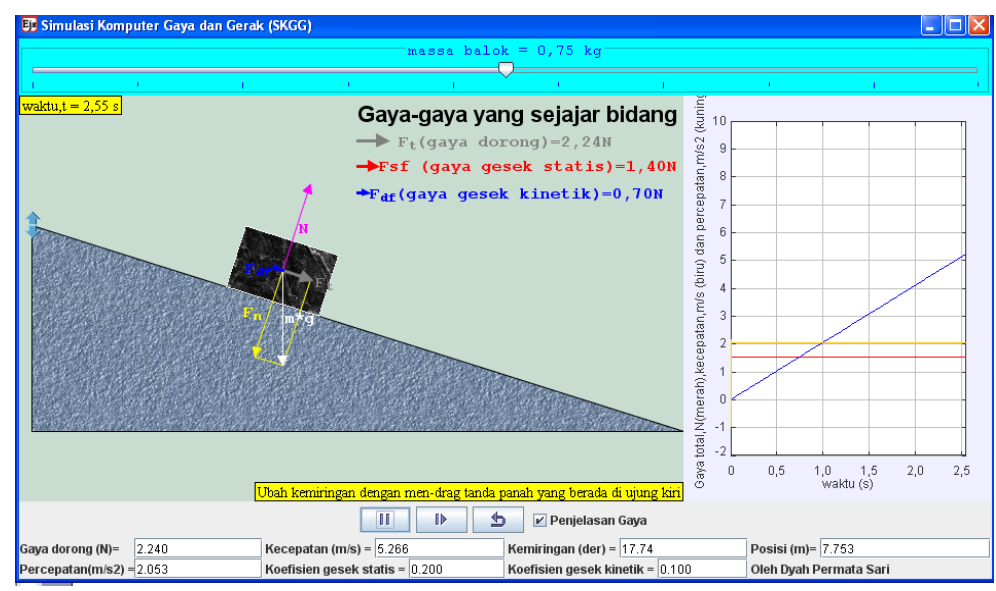

Figure 4. A screenshot of a simulation that represents a block sliding on a ramp plane and graphical presentation of motion.

Initially, the block stays at rest on the ramp plane and is pulled by gravitation force. If the force begins to move the block, then the kinetic friction forces the block to start moving (yellow arrow), and the block moves with velocity, v (blue) (Figure 4). When the mass (m) of the block is increased by dragging the right slider, the friction force is increased and is lower than this limit. When the coefficient of friction is increased by dragging the right slider, the total force is decreased and is lower than this limit, as are the friction force and the system force. When the initial position of the block is increased by dragging the right slider, the force is increased and is lower than this limit and the friction force and system force. This simulation leads the students to the logical and conceptual meaning of the statement: motion does not need a cause, but a change in motion does.
Integrating the differential equation of Newton's law for motion of the block under chance of the forces can derive equations of motion.

Thus, if the initial variables, i.e., the net force and object mass are known, the parameters of position, i.e., the velocity and acceleration, can be determined at any given instant of time. Students can explore the motion of the block along the incline with different initial variables, a changing slope of the plane and the coefficient of static and dynamic friction. Although the initial position and velocity can change, the forms of the graphs do not change. There is always motion with constant acceleration under a constant net force. Working with similar examples of simulations, students can explore motion under a specific force (constant force, restoring force, resistive 
force or central force), thereby helping students correct their preconceived ideas about Newton's Laws and other physics phenomena $[6,14,15,16,18]$.

\section{Implementation}

Regardless of whether the end use of the computer simulation will be in the classroom or the laboratory, it is necessary to test the computer simulation with actual learners. The purpose of this part is to introduce the computer simulation in an effective and efficient way. During this phase, the students should be supported to ensure that they understand Newton's second law and that they are aware of the objectives of the simulation. There should be no doubt that Newton's second law is being taught to the learner.

\section{Evaluation}

This is the process of determining whether the instruction is sufficient and measuring the effect of the simulation to discover the extent to which the computer simulation meets the learning objectives and the learners' needs. The evaluation is directly related to each of the previous four stages, and it may be necessary to return to one of the previous stages at the end of this phase. Moreover, at the end of each stage, an evaluation is conducted to ensure that the process is being carried out in a sound manner. Then, at the end of each evaluation, modifications, if necessary, are made for the next implementation. However, the resources and implementations appropriate for understanding this new way of learning are still limited. Therefore, it is necessary to develop computer simulation learning environments further, and this study aims to contribute to this need [14].

\section{Evaluation of Students' Competence of Newton's Second Law}

This is a quasi-experimental study to examine the hypothesis that there is no significant difference in the conceptual competence of Newton's second law between students taught using the computer simulation and those taught without the simulation. The study used a non-randomized pre/post-test control group design. This design was adopted to determine the effects of the computer simulation on students' conceptual competence of Newton's second law. The performance on the pretest was used to compare the entry behavior or previous knowledge of the groups involved in the study. It also helped check the sampling error inherent in the random sampling method, which is based on chance. The post-test was used to assess the knowledge gained after the lessons.

As an example, to test the understanding of force and motion concepts, students were asked the following conceptual questions in class group work (they had already completed a study of kinematics in their physics classes): How do the gravity force, normal force, and driven force affect the block versus time when the block is sliding on the ramp? How do the position, velocity, and acceleration change versus time when the block is sliding on the ramp plane? What is the connection between motion and the forces acting on the block? Students wrote their predictions and discussed their answers with each other. For many students, all quantities of force, position, velocity, and acceleration increased linearly with respect to time. In their replies, force had nothing to do with change of speed; the forces (friction force, driven force, normal force and gravity force) were needed to keep the block moving. Most of the 
students replied that the block is not free to go up the ramp plane, that force gives the block an initial velocity and that it accelerates. Students believed that a constant force is required to keep an object in motion at a decrease velocity and that when the velocity is decreased, both the acceleration and force must decrease. The motion of the block sliding on the ramp plane is not motion with constant force, which is why the velocity decreased.

$\mathrm{O}_{1}$ and $\mathrm{O}_{3}$ were the pre-test scores; $\mathrm{O}_{2}$ and $\mathrm{O}_{4}$ were the post-test scores; and $\mathrm{X}$ (= computer simulation) was the treatment where students were taught using computer simulation. Group 1 was the experimental class that received the pre-test, the treatment $\mathrm{X}$ and the post-test. Group 2 was the control group that received a pre-test followed by the control condition and then the post-test. Group 2 was taught using the $\mathrm{T}$ (=traditional) method. The Research design is represented in Figure 5.

\begin{tabular}{ccc}
\hline $\mathrm{O}_{1}$ & $\mathrm{X}$ & $\mathrm{O}_{2}$ \\
\hline $\mathrm{O}_{3}$ & $\mathrm{~T}$ & $\mathrm{O}_{4}$ \\
\hline
\end{tabular}

Figure 5. Quasi-Experiment Research Design.

The unit of sampling was third-semester physics education students in the Physics Department, Mathematics and Science Faculty, State University of Surabaya (UNESA). This means that none of the students in each group had studied the seven topics. The researchers visited the groups to determine whether they were suitable for research. During the visit, the researcher established that there were other trained lecturers in the classes and obtained information on the class composition and learner characteristics from Department records. The sample size of Group 1 (Experimental group) was $\mathrm{N}=38$, and that of group 2 (Control group) was $\mathrm{N}=38$.
Therefore, the sample size in the research was 80. Fraenkel and Wallen [21; 22] recommend at least 30 subjects per group. Hence, this number was adequate for the study.

\section{RESULT AND DISCUSSION}

To analyze data in this study, we used Microsoft Excel. The results of the pre-test scores on Force Motion Conceptual Evaluation (FMCE) for groups 1 and 2 were statistically significant equal, with a mean of 20.72 for the experimental group and 22.96 for the control group (Table 1). The results of the two-sample test are shown in Table 1. Excel calculated the test statistic and critical values for the test. Recall that if the test statistic is less than -1.993 or greater than 1.993 , we reject the null hypothesis in favor of the alternative. The test statistic is 1.596, which is in the acceptable region, so we accept the null hypothesis of no difference between the means from the two samples. In other words, we accept that the mean of both pre-test scores is equal, with $95 \%$ confidence. This indicated that the groups used in the study exhibited comparable characteristics. The groups were suitable for the study when comparing the improvement effects of $\mathrm{X}$ and $\mathrm{T}$ on force motion conceptual competence. The results of the pre-test scores on FMCE for groups 1 and 2 showed a statistically significant equal.

Two-sample hypothesis testing is a statistical analysis method that was designed to test whether there is a difference between two means from two different populations. To examine the difference between the mean post-test scores of the experimental group and the control group, we used a t-test. The results are shown in Table 2. 
Table 1. Results of pretest score calculation using

\begin{tabular}{lll}
\multicolumn{3}{c}{ t-test } \\
\hline \multicolumn{3}{c}{ t-Test: Two-Sample Assuming Equal Variances } \\
\hline & Cariable 1 & Variable 2 \\
\hline Mean & 20,71668533 & 22,95632699 \\
Variance & 23,4138501 & 51,42546945 \\
Observations & 38 & 38 \\
Pooled Variance & 37,41965978 & \\
Hypothesized & \\
Mean & \\
Difference & 0 \\
df & 74 \\
t Stat & $-1,595899064$ \\
P(T<=t) one-tail & 0,057386733 \\
t Critical one-tail & 1,665706893 \\
P(T<=t) two-tail & 0,114773467 \\
t Critical two-tail & 1,992543466 & \\
\hline
\end{tabular}

Table 2. Results of post-test scores calculation

\begin{tabular}{lll}
\multicolumn{3}{c}{ using t-test } \\
\hline \multicolumn{3}{c}{ t-Test: Two-Sample Assuming Equal Variances } \\
\hline & Control group & Experiment group \\
\hline Mean & 43,89697648 & 70,21276596 \\
Variance & 80,11967079 & 87,60231485 \\
Observations & 38 & 38 \\
Pooled Variance & 83,86099282 & \\
Hypothesized $\quad$ Mean & & \\
Difference & 0 & \\
df & 74 \\
t Stat & $-12,52602298$ & \\
P(T<=t) one-tail & $2,88983 \mathrm{E}-20$ & \\
t Critical one-tail & 1,665706893 & \\
P(T<=t) two-tail & $5,77966 \mathrm{E}-20$ & \\
t Critical two-tail & 1,992543466 & \\
\hline
\end{tabular}

The results of the two post-test scores are shown in Table 2. Excel calculated the test statistic and critical values for the test. Recall that if the test statistic is less than -1.993 or greater than 1.993 , we reject the null hypothesis in favor of the alternative. The test statistic is 12.526 , which is in the rejection region, so we reject the null hypothesis of no difference between the means from the two samples. In other words, we reject that the mean amount pre-test scores is equal to the mean amount post-test scores, with 95\% confidence. The mean score of the experimental group is 70.2 , which is higher than that of the control group, at 43.9. The normalized gain score of the experimental group ( 0.61 classified medium) is greater than that of the control group $(0.29=$ low $)$ [23] (Table 3). This finding indicates that the computer simulation implementation in teaching and learning can improve the conceptual competence of Newton's second law of motion.

Table 3. Comparison between experimental and

\begin{tabular}{cccc}
\multicolumn{4}{c}{ control groups } \\
\hline Grouplscore & Mean & Mean & Normalized \\
& pre-test & post-test & gain \\
\hline Experimental & 22.96 & 70.21 & 0.61 \\
Control & 20.72 & 43.89 & 0.29 \\
\hline
\end{tabular}

Understanding Newton's second law is the key to understanding mechanics. Before the introduction of Newton's second law. Students should know the definitions of the terms motion, force and mass. Rushing to problem-solving only enhances the students' ability to manipulate the equations of motion and does not result in Newtonian conceptual understanding. It is essential to provide context for the law of motion and show how the law is to be used. Our computer simulation concentrates on how the second law determines motion of a particle under the different forces and the development of individual experience, such as the use of simulations. The students learn better when they are faced with a computer simulation because simulations utilize two sources of information: one source from authority and the other from direct experience. Using EJS is an effective 
educational practice that supports conceptual understanding of Newton second law of motion. The ability to change variables and explore in real time the forces and graphs of motion provides students, in a very short time, with the ability to correct their preconceived ideas and develop a clear sense of the relationship between force and motion.

\section{CONCLUSION}

There is a significant improvement in the conceptual competence of Newton's second law in students taught using the computer simulation compared to those taught without the simulation. The mean scores of the experimental group (using computer simulation) were greater than those of the control group (without computer simulation/ traditional.

\section{ACKNOWLEDGMENT}

My thanks to Esquembre F (2009) http://www.um.es/fem/EjsWiki/Main/Docu mentation and to Fu-Kwun Hwang http://www.phy.ntnu.edu.tw/ntnujava/. I also thank Andrew Duffy http://physics.bu.edu/ duffy/Ejs/EP_chapte r12/spring_v2e.html and Loo Kang wee. All of them gave me the inspiration to design the computer simulation. I also give my thanks to the anonymous reviewers for helpful comments to improve this article.

\section{REFERENCES}

[1] Brandsford et al. How People Learn. National Academy Press; 2000.

[2] Jimoyiannis K. Computer Simulations in Physics Teaching and Learning. Comp. Educ. 2001; 36.

[3] Lederman. American Renaissance in Science Education. FERMILAB-TM-2051; 1998.

[4] Hallouna IA and Hestenes D. Common Sense Concepts about Motion. Am. J. Phys.
1985; 53 (11).

[5] McDermott, et al. Student Difficulties in Connecting Graphs and Physics: Examples from Kinematics. Am. J. Phys. 1987; 55 (6).

[6] Arons AB. Teaching Introductory Physics. Wiley; 1997.

[7] Sessa, DI. Changing Minds. MIT Press; 2000.

[8] Christian W and Esquembre F. Modeling Physics with Easy JavaSimulations. The Physics Teacher. 2007; 45. Available from: DOI: $10.1119 / 1.2798358$.

[9] The Open Source Physics (OSP). Available from: http://www.compadre.org/osp.

[10] Esquembre F. 2009. Available from: http://www.um.es/fem/EjsWiki/Main/Docu mentation [Accessed 14th September 2014].

[11] Sommerville, I. Software Engineering, 3rd ed. Reading: MA Addison-Wesley; 1989.

[12] IEEE. Reference Guide for Instructional Design and Development, available online at www.ieee.org; 2001.

[13] AskERIC. An AskERIC Write-A-Lesson Plan Guide, available online at www.askeric.org; 1999.

[14] Arkün S and Akkoyunlu B. A Study on the Development Process of a Multimedia Learning Environment According to the ADDIE Model and Students' Opinions of the Multimedia Learning Environment. Interactive Educational Multimedia. 2008; 17: 1-19. Available from: http://www.ub.edu/multimedia/iem/iemjorn al@greav.net.

[15] Fu-Kwun-Hwang. Available from: http://www.phy.ntnu.edu.tw/ntnujava/.

[16] Wee, Loo Kang, Goh, Giam Hwee, Chew, Charles. 20 Enabling Gravity Physics by Inquiry using Easy Java Simulation. Paper presented at The 5th Redesign Pedagogy, Singapore. Available from: http://arxiv.org/ftp/arxiv/papers/1303/1303. 0079.pdf

[17] Christian W, Esquembre F, Barbato L. Open Source Physics. Science. 2011; 334 
(6059), 1077-1078. Available from: doi: 10.1126/science.1196984

[18] Duffy, Andrew. Available from: http://physics.bu.edu/ duffy/Ejs/EP_chapter 12/spring_v2e.html; 2009.

[19] Madlazim. Metode Praktis Mendesain Simulasi Fisika Interaktif. Surabaya: UNESA University Press; 2007.

[20] Madlazim. Membuat Eksperimen Virtual Lukisan Lissajous Menggunakan Opensource Easy Java Simulation. Available from: http://file.upi.edu/Direktori/FPMIPA/JUR. PEND._FISIKA/196302071991031-WASL ALUDDIN/STEP_LISSAJOUS_EJS.pdf; 2008.

[21] Madlazim and Supriyono. Improving
Experiment Design skills: Using the Joko Tingkir Program as a Learning Tool of Tsunami Topic. Science of Tsunami Hazards. 2014; 33 (2): 133-143.

[22] Fraenkel J.R and Wallen N.E. How to Design and Evaluate Research in Education, New York: Mc Graw-Hill Companies Inc; 2000.

[23] Hake, R.R. Interactive-engagement vs Traditional Methods: A Six-Thousand-Student Survey of Mechanics Test Data for Introductory Physics Courses. Am. J. Phys. 1998; 66(1) 64-74. Available from:

http://www.physics.indiana.edu/ sdi/>. 